\title{
Laparoscopic surgery in a paediatric patient with Down's syndrome and patent foramen ovale
}

\author{
Sarita Singh, ${ }^{1}$ Reetu Verma, ${ }^{1}$ Anand Pandey, ${ }^{2}$ Chetna Tandon, ${ }^{1}$ Ashish Wakhlu, ${ }^{2}$ Aman Agarwal ${ }^{1}$
}

1Department of Anesthesiology, CSMMU (formerly King George's Medical University), Lucknow, India;

2Department of Pediatric Surgery, CSMMU (formerly King George's Medical University), Lucknow, India

Correspondence toDr Anand Pandey, dranand27@rediffmail.com

\begin{abstract}
Summary
The safety of laparoscopic surgery in infants with congenital heart disease has been a subject of controversy despite potential benefits over open surgery. The authors present the anaesthetic management of a 6-month-old female infant with Down's syndrome with a small patent foramen ovale with left to right shunt who successfully underwent laparoscopic coloplasty. There were no intraoperative or postoperative complications. In addition to the routine anaesthetic considerations for any surgical patient, the choice of the anaesthetic technique in patients undergoing laparoscopic procedures should consider the effect on the patient's underlying cardiorespiratory function of pneumoperitoneum and carbon dioxide insufflation.
\end{abstract}

\section{CASE PRESENTATION}

A 6-month-old female child having anorectal malformation was posted for laparoscopic coloplasty. Pelvic colostomy was performed when she was 2-days-old. She had history of cyanotic spells 1 month after her first surgery and was diagnosed to be have a patent foramen ovale (PFO). The patient also had history of recurrent chest infections. Her weight was $2.8 \mathrm{~kg}$. Airway examination appeared to be normal. On cardiovascular examination, heart sounds were normal but a murmur was heard. The respiratory system was within normal limits and laboratory investigations were within normal limits. The 2D echocardiogram of the patient revealed small $\mathrm{PFO}$ with left to right shunt.

After taking informed consent, the patient was taken to theatre. The heart rate (HR) was $164 / \mathrm{min}, \mathrm{SpO}_{2} 100 \%$, with normal temperature. Antibiotics were administered for endocarditis prophylaxis. The patient was premedicated with intravenous fentanyl $(2 \mu \mathrm{g} / \mathrm{kg})$ and atropine (0.01 $\mathrm{mg} / \mathrm{kg}$ ). Inhalational induction was performed with halothane, $\mathrm{O}_{2}$ and $\mathrm{N}_{2} \mathrm{O}$. She was intubated with an endotracheal tube of internal diameter $4 \mathrm{~mm}$ and endotracheal $\mathrm{CO}_{2}\left(\mathrm{ETCO}_{2}\right)$ was connected. Intraoperatively, the patient was maintained on $\mathrm{O}_{2}, \mathrm{~N}_{2} \mathrm{O}$, isoflurane and atracurium $(0.1 \mathrm{mg} / \mathrm{kg})$. The concentration of isoflurane was titrated to haemodynamic parameters. The peritoneal cavity was insufflated with $\mathrm{CO}_{2}$ at a maximum pressure of $8 \mathrm{~mm} \mathrm{Hg}$ at flow of $1 \mathrm{l} / \mathrm{min}$. She was plaved at 30 degrees in the Trendelenburg position. Pressure controlled ventilation was used to prevent high peak inspiratory pressure and minute ventilation was increased to main normocarbia. Intraoperatively, the HR ranged between 164 and 210/min, $\mathrm{SpO}_{2}$ 98-100\%, and $\mathrm{ETCO}_{2} 28-44$ $\mathrm{mm} \mathrm{Hg}$. The patient was reversed with neostigmine $(0.005 \mathrm{mg} / \mathrm{kg})$ and atropine $(0.01 \mathrm{mg} / \mathrm{kg})$ and patient was extubated.

\section{OUTCOME AND FOLLOW-UP}

Postoperatively, the patient was taken to paediatric intensive care unit for monitoring. The postoperative course was uneventful.

\section{DISCUSSION}

Down's syndrome, also known as Trisomy 21, is one of the most common congenital anomalies, occurring in about 1 in 800-1000 live births. ${ }^{1}$ Many organ systems may be involved in Down's syndrome, especially cardiovascular, respiratory and central nervous system (CNS), which may pose anaesthetic challenges. Down's syndrome patients have decreased CNS catecholamine levels which may result in decreased minimum alveolar concentration level. ${ }^{2}$ Atropine hypersensitivity has been noted in these patients; hence, sensitivity to atropine needs to be evaluated before giving a vagolytic dose. ${ }^{3}$ Due to the presence of muscular hypotonia, ${ }^{1}$ muscle relaxants need to be used with care.

Laparoscopic coloplasty was planned in this patient to decrease postoperative pulmonary dysfunction due to decreased operative time. This approach, with proper monitoring and postoperative ICU care, may be the preferred in this type of patients. ${ }^{4}$ The intra-arterial pressure (IAP) level is a major determinant of cardiorespiratory changes during laparoscopy. The cardiovascular response to increased IAP involves changes in preload, systemic vascular resistance and myocardial contractility. ${ }^{5} 6$ A study using trans-oesophageal echocardiography during paediatric laparoscopy has shown that cardiac index (CI) decreases approximately $13 \%$ at an IAP of $12 \mathrm{~mm} \mathrm{Hg}$ in healthy children with no adverse effects at an IAP of $6 \mathrm{~mm}$ $\mathrm{Hg} .{ }^{7}$ As decreased CI may reduce shunt flow, which may result in desaturation, a maximum IAP of $12 \mathrm{~mm} \mathrm{Hg}$ has been recommended for patients with cardiac disease. ${ }^{8}$

The increase in IAP also affects respiratory function. In infants, a reduction of functional residual capacity (FRC) 


\section{BMJ Case Reports}

due to pneumoperitoneum and raised IAP causes alveolar collapse, increased venous admixture and oxygen desaturation more rapidly than in adults. ${ }^{9}$ Prevention of atelectasis with an adequate tidal volume and positive end expiratory pressure preserves FRC. ${ }^{8}$ Inspired oxygen concentration should be the minimum necessary to achieve baseline oxygen saturation. Hyperoxia decreases peripheral vascular resistance leading to pulmonary over-circulation and decreased systemic perfusion. Absorption of $\mathrm{CO}_{2}$ can be significant and an increase in minute ventilation is required to maintain normocarbia. ${ }^{10-12}$

As our patient was a diagnosed case of Down's syndrome, we anticipated a difficult intubation and planned for inhalational induction. As subglottic stenosis is well reported in these patients, ${ }^{13}$ we used an endotracheal tube $0.5 \mathrm{~mm}$ diameter smaller than the standard age appropriate endotracheal tube size. Atlantoaxial instability has been reported in $20 \%$ of patients with spinal cord compression in $2 \%$, so we kept the head and neck in neutral position. ${ }^{14} 15$ Intraoperative hypothermia, hypercarbia and hypoxemia are known to cause shunt reversal. These were avoided by detailed monitoring of the patient.

\section{Learning points}

- Intubation in patient of Down's syndrome can be difficult due to subglottic stenosis, large tongue and sensitivity to atropine, hence, extra vigilance is important.

- Cardiac lesions may make anaesthesia challenging.

- Muscular hypotonia means care must be taken when using muscle relaxants.

- Capnography is important to assess the effect of pneumoperitoneum.
Competing interests None.

Patient consent Obtained.

\section{REFERENCES}

1. Yang $\mathbf{0}$, Rasmussen SA, Friedman JM. Mortality associated with Down's syndrome in USA from 1983-1997: a population based study. Lancet 2002;359:1019-25.

2. Keele DK, Richards C, Brown J, et al. Catecholamine metabolism in Down's syndrome. Am J Ment Defic 1969;74:125-9.

3. Mir GH, Cumming GR. Response to atropine in Down's syndrome. Arch Dis Child 1971;46:61-5..

4. Collins JB, Georgeson KE, Vicente Y, et al. Comparison of open and laparoscopic gastrostomy and fundoplication in 120 patients. J Pediatr Surg 1995;30:1065-70.

5. Richardson JD, Trinkle JK. Hemodynamic and respiratory alterations with increased intra-abdominal pressure. J Surg Res 1976;20:401-4.

6. Tobias JD, Halcomb GW, Brock JW, et al. Cardiorespiratory changes in children during laparoscopy. J Pediatr Surg 1995;30:33-6.

7. Sakka SG, Huettemann E, Petrat G, et al. Transesophageal echocardiographic assessment of haemodynamic changes during laproscopic herniorrhaphy in small children. Br J Anaesth 2000:84:330-4.

8. Pennant JH. Anesthesia for laproscopy in the pediatric patient. Anesthesiol Clin North America 2001;19:69-88.

9. Pighin G, Crozier TA, Weyland W, et al. Specifies of anaesthesiology in laparoscopic surgery in infancy. Zentralb/ Chir 1993;118:628-30.

10. Petrat G, Weyandt D, Klein U. Anesthetic considerations in pediatric laparoscopic and thoracoscopic surgery. Eur J Pediatr Surg 1999;9:282-5.

11. Walsh MT, Vetter TR. Anesthesia for pediatric laparoscopic cholecystectomy $J$ Clin Anesth 1992;4:406-8.

12. Puri GD, Singh $\mathrm{H}$. Ventilatory effects of laparoscopy under general anaesthesia. Br J Anaesth 1992;68:211-13.

13. Miller R, Gray SD, Cotton RT, et al. Subglottic stenosis and Down syndrome. Am J Otolaryngol 1990;11:274-7.

14. Bhattarai B, Kulkarni AH, Rao ST. Anaesthetic consideration in down syndrome- a review. Nepal Med Coll J 2008;10:199-203.

15. Mitchell V, Howard R, Facer E. Down's syndrome and anaesthesia. Paediatr Anaesth 1995;5:379-84.

This pdf has been created automatically from the final edited text and images.

Copyright 2011 BMJ Publishing Group. All rights reserved. For permission to reuse any of this content visit http://group.bmj.com/group/rights-licensing/permissions.

BMJ Case Report Fellows may re-use this article for personal use and teaching without any further permission.

Please cite this article as follows (you will need to access the article online to obtain the date of publication).

Singh S, Verma R, Pandey A, Tandon C, Wakhlu A, Agarwal A. Laparoscopic surgery in a paediatric patient with Down's syndrome and patent foramen ovale. BMJ Case Reports 2011;10.1136/bcr.09.2010.3334, date of publication

Become a Fellow of BMJ Case Reports today and you can:

- Submit as many cases as you like

- Enjoy fast sympathetic peer review and rapid publication of accepted articles

- Access all the published articles

- Re-use any of the published material for personal use and teaching without further permission

For information on Institutional Fellowships contact consortiasales@bmjgroup.com

Visit casereports.bmi.com for more articles like this and to become a Fellow 